\title{
Digital Based Learning Media Innovation in the Development of Character Education in Senior High School
}

\section{Inovasi Media Pembelajaran Berbasis Digital Dalam Pengembangan Pendidikan Karakter di Madrasah Aliyah}

\author{
Evi Fatimatur Rusydiyah*, Nurotun Mumtahanah, Fachrizal Hamzah \\ Universitas Islam Negeri Sunan Ampel Surabaya, Indonesia
}

In the era of digital learning, educational institutions must innovate to meet the changing needs of the times. The efforts of educational institutions to make their creations and innovations a challenge. The innovation carried out by educational institutions aim to equip student competencies according to their time. The purpose of this study is to analyze the innovation of digital-based learning media in the development of character education in MAN I Lamongan. This research method uses case studies with an interview, observation, and documentation data collection techniques. While the data analysis uses the theory of Miles and Huberman, which begins with reducing data, presenting data, and drawing conclusions. The results indicated that 1) MAN 1 Lamongan encourage the inoovation through implementation Vision-mission; 2) learning process using positive internet using varied learning media in the form of slides, dynamic visuals that are projected, printed, games, and reality media, and 3) programs of activities including Adiwiyata school programs, ISO programs, D1 equivalent production programs in collaboration with ITS, and Ma'had for sons and daughters. All services connected with Information Technology.

Reviewed by: Deni Adi Putra

*Correspondence:

Evi Fatimatur Rusydiyah

evifatimatur@uinsby.ac.id

Received: 1 Juni 2020

Accepted: 3 Juni 2020

Published: 11 Desember 2020

Citation:

Rusydiyah EF, Mumtahanah N and Hamzah F (2020) Digital Based Learning Media Innovation in the

Development of Character Education in Senior High School.

Pedagogia: Jurnal Pendidikan. 10:1. doi: 10.21070/pedagogia.v10vi1i.4
Keywords: Learning Media Innovation, Digital Media, Character Education

Pada era pembelajaran digital, lembaga pendidikan harus berinovasi untuk memenuhi kebutuhan perubahan zaman. Usaha lembaga pendidikan untuk membuat kreasi dan inovasi menjadi tantangan bagi mereka. Inovasi-inovasi yang dilakukan oleh lembaga pendidikan tersebut bertujuan untuk membekali kompetensi mahasiswa sesuai dengan masanya. Tujuan dari penelitian ini adalah untuk menganalisis inovasi media pembelajaran berbasis digital dalam pengembangan pendidikan karakter di MAN I Lamongan. Metode penelitian ini menggunakan studi kasus dengan tehnik pengumpulan data wawancara, observasi, dan dokumentasi. Sedengakan analisis datanya menggunakan teori Miles and Huberman yang diawali dengan mereduksi data, penyajian data, dan penarikan kesimpulan. Hasil dari penelitian ini adalah inovasi media pembelajaran berbasis digital dalam pengembangan pendidikan karakter di MAN 1 Lamongan tecermin dalam tiga bagian, 
yaitu 1) MAN 1 Lamongan mendorong program inovasinya melalui Visi-misi yang dimilik, 2) proses pembalajaran dengan menggunakan internet positif dengan menggunakan media pembelajaran yang bervariasi berupa slide, visual dinamis yang di proyeksikan, cetak, game, dan media realita, dan 3) progam kegiatan yeng meliputi program sekolah adiwiyata, program ISO, progam prodistik setara D1 yang bekerja sama dengan ITS, dan Ma'had putra dan putri . semua layanan terhubung dengan Teknologi Informasi.

Kata Kunci: Inovasi Media Pembelajaran, Media Digital, Pendidikan Karakter 


\section{PENDAHULUAN}

Perubahan era 4,0 ditandai dengan perubahan segala aspek dalam kehidupan, termasuk pada bidang pendidikan. Pendidikan saat ini dituntut untuk membuat inovasi-inovasi baru terutama dalam melayani pembelajaran tidak hanya offline, tetapi juga yang online/daring. Konsep inovasi tidak sebatas sebuah produk, inovasi dapat berupa cara, ide atau obyek yang dianggap sebagai suatu pembaruan. Inovasi juga mengacu pada sebuah perubahan yang dialami dan diamini oleh masyarakat Suryani (2008). Demikian juga inovasi merupakan suatu hal baru dalam tataran masyarakat yang biasa digunakan untuk menyelesaikan suatu masalah. Inovasi memiliki 4 jenis, yaitu Penemuan (Invention), Pengembangan (Extension), Duplikasi (Duplication), dan sintesis (Synthesis) Sanjaya (2008). Dalam dunia pendidikan, inovasi sangat diperlukan. Melalui inovasi akan meningkatkan kemampuan agar dapat mencapi suatu tujuan tertentu dalm dunia pendidikan. Karakteristik suatu perubahan inovasi adalah (1) baru, adanya perbedaan sifat kualitatif dari sebelumnya dan belum pernah ada, (2) kualitatif, penyusunan kembali terhadap komponenkomponen pendidikan, (3) hal, adanya pembaruan pada subsistem pendidikan dalam hal komponen dan aspek, (4) kesengajaan, melakukan oembaruan pada pendidikan degan sengaja dan sudah terencana, (5) meningkatkan kemampuan, peningkatan kemmapuan dari segala aspek, termasuk tenaga, uang, dan sarana, dan (6) tujuan, merinci secara jelas mengenai sasaran dan tujuan. Tingkatan inovasi pendidikan mencakup inovasi kurikulum (berbasis masyarakat, kompetensi, keterpaduan), inovasi pembelajaran (kontekstual, kuantum, kompetensi), dan inovasi melalui teknologi informasi (internet) (pembelajaran elektronik, internet, dan disajikan melalui teknologi informasi. Widyartono (213)

Inovasi dalam bidang digital learning ditandai dengan banyaknya kecenderungan masyarakat menggunakan sistem online dalam pelayanan pembelajarannya. Ada dua konsepsi dasar tentang digital learning atau e-learning secara umum, Pertama. Electronic based e-Learning yaitu pemanfaatan teknologi informasi dan komunikasi, terutama yang berupa elektronik sebagai media pembelajaran. Artinya dalam pemanfaatnnya bukan hanya sekeder menggunakan internet, melainkan semua alat elektronik seperti film, vidio, kaset, OHP, Slide, LCD, Projector, dan lain sebagainnya. Kedua, internet-based yaitu pemanfaatan internet sebagi instrumen utama dalam pembelejaran Jenkins and Hanson (2003). Hal tersebut diperkuat oleh Koran (2000); Effendi and Zhuang (2005); Rusman et al. (2013) bahwa melalui e-Learning, sekolah dapat memanfaatkan media elektronik sebagai media pembelajaran (LAN, WAN, atau internet) untuk menyampaikan isi pembelajaran, interaksi, atau bimbingan. E-learning ini merupakan media pembelajaran digital Sanaky (2015). Media pembelajaran merujuk pada artian alat-alat grafis, photografis, atau elektronis untuk menangkap, memproses, dan menyusun kembali informasi visual atau verbal yang bersifat offline maupun online Arsyad (2005).
Dalam konteks Indonesia, perkembangan teknologi yang semakin massive dalam semua lini kehidupan masyarakat harus direspon secara bijak oleh dunia pendidikan. Presiden RI melalui perpres No 87 Tahun 2017 mengeluarkan Peraturan Presiden RI tentang Penguatan Pendidikan Karakter (Perpres No 87 Tahun 2017, 2017). Dalam perpres tersebut dinyatakan bahwa penguatan karakter menjadi tanggungjawab bersama baik pendidikan formal, informal, maupun non formal. Dalam perpres tersebut terdapat 18 karakter yang perlu diperkuat dalam sistem pendidikan. Karakter-karakter tersebut adalah nilai-nilai religius, jujur, toleran, disiplin, bekerja keras, kreatif, mandiri, demokratis, rasa ingin tahu, semangat kebangsaan, cinta tanah air, menghargai prestasi, komunikatif, cinta damai, gemar membaca, peduli lingkungan, peduli sosial, dan bertanggung jawab. Pendidikan karakter diatas diartikan sebagai bentuk upaya dan kesungguhan dari seorang tenaga didik dalam memberikan pengajaran mengenai nilainilai kepada peserta didiknya. Pendidikan karakter temasuk dalam pergerakan pendidikan yang memberi dukungan terhadap perkembangan sosial, pengembangan emosional, serta pengembangan etik para peserta didik Samani and Hariyanto (2012) . Hal ini diperkuat oleh Kusuma (2004) mengartikan pendidikan karakter sebagai pola tumbuh kembang kemampuan secara bertahap dan terus-menerus denagn diri sendiri untuk menghasilkan nilai positif pada diri sendiri dan stabil dalam diri individu. Pola seperti ini akan menumbuhkan pribadi yang kuat dan utuh. Unsur-unsur ini lingkungan yang meproses jiwa dan membentuk formasi pada setiap pribadi Kusuma (2004). Sedangkan pendidikan karakter dalam Islam diartikan sebagi bentuk usaha untuk menanamkan kemampuan pada peserta didik, bersikap, dan berperilaku sesuai dengan nilai-nilai luhur yang menjadi jati dirinya, diwujudkan dalam intraksi dengan Tuhannya, diri sendiri, antar sesama, dan lingkungannya sebagai manifestasi hambah dan khalifah Allah Purwati et al. (2012) .

Pendidikan karakter pada tingkat satuan pendidikan merupakan masa fondasi awal dari terbentuknya budaya sekolah ataupun madrasah, yaitu nilai-nilai yang melandasi perilaku, tradisi, kebiasaan sehari-hari, serta simbol-simbol yang dipratikkan oleh semua masyarakat sekolah dan masyarakat sekitar. Budaya sekolah atau madrasah merupakan ciri khas, karakter atau watak, dan citra sekolah tersebut di mata masyarakat luas Mulyasa (2011). Perpaduan antara inovasi pembelajaran pada bidang digital learning sebagai bagain dari media pembelajaran dengan tetap menjalankan penguatan pendidikan karakter belum banyka dilakukan. Oleh karena penelitian ini akan menfokuskan pada bagaimana upaya inovasi Madrasah Aliyah Negeri (MAN) 1 Lamongan dalam mengimplementasikan media pembelajaran berbasis digital learning dalam pengembangan pendidikan karakter. Penelitian ini sebagai upaya dalam menerjemahkan atau merespon tantangan perilaku yang kurang baik pada era digital ini dengan mendorong dan mendesain pembelajaran digital dan internet yang positif sebagai bagian dari impelemntasi proses penguatan karakter. 


\section{METODE}

Metode penelitian ini menggunakan pendakatn kualitatif dengan mendeskripisakan situasi-situasi nyata yang ada di lapangan. Tehnik pengumpulan data dilakukan dengan observasi, angket, wawancaraa dan dokumentasi. Teknik observasi dilakukan dengan menggunakan observasi partisipan, yang mana peneliti akan langsung terjun dalam pembelajaran di kelas. observasi ini melibatkan keikutsertaan peneliti dengan individu atau suatu komunitas yang diobservasi. Angket diberikan kepada informan untuk dijawab. Selanjutnya pengumpulan data dengan wawancara dilaksanakan dengan tatap muka. Penelitian ini menggunakan wawancara tidk terstuktur, dalam hal ini peneliti tidak mengunakan pedoman wawancara yang sudah terencana dengan sistmatis. Pedoman wawancara berupa garis-garis besar masalah. Kemudian dokumetasi yang dimaksud dalam penelitian ini merupakan dokumentasi berupa foto atau video yang menggambarkan kondisi sekolah. Fokus penelitian ini adalah pada upaya inovasi MAN I Lamongan dalam mengembangkan media digital leearning dalam Pengembangan Pendidikan Karakter. Infroman dalam penelitian ini adalah Kepala Sekolah, Guru, dan Siswa-siswi. Setelah data terkumpul maka peneliti menganalisis data tersebut dengan tenik analisis menurut metode Miles and Huberman (2015), dengan mereduksi data dan melakukan penyajian data, kemudian yang terkahir melakukan penarikan kesimpulan.

\section{HASIL DAN PEMBAHASAN}

\section{Visi-misi Madrasah dalam Menggerakkan Program Inovasi Digital Learning}

Penelitian tentang inovasi pendidikan telah banyak dilakukan dibeberapa negara. Inovasi pendidikan dalam pemanfaatan digital learning dilakukan oleh Ahmed et al. (2018) tentang faktor-faktor yang mempengaruhi penggunaan e-learning di Pakistan. Ia menemukan ada dua hal penting di Pakistan dalam pemanfaatan e-Laerning, pertama adalah inftastruktur sistem jaringan dan parameter yang spesifik dari negara lain. Kedua temuan tersebut mengindikasikan bahwa sistem jaringan dan parameter dari negara lain menjadi hal penting dalam menerapkan e-learning di Pakistan. Sistem jaringan dan parameter tidak menjadi hal penting bagi Bashir (2019) . Dia menemukan hal postif dalam pembelajaran e-learning di Uganda. Dia menemukan bahwa pembelajaran yang difasilitasi media e-learning dapat menjadi bukti adanya pembelajaran dengan tingkat kepuasan siswa yang lebih baik dari pada menggunakan pembelajaran yang offline. Hal ini membuktikan bahwa meskipun pembelajaran online lebih banyak membutuhkan waktu, tetapi tingkat kepuasan dan motivasi untuk belajar lebih tinggi daripada belajar offline. Demikian juga yang ditemukan dalam penelitian ini. Inovasi digital yang ada di MAN 1 Lamongan dalam pengembangan pendidikan karakter dapat dilihat dalam visi-misi MAN 1 Lamongan. Dalam visi MAN 1 Lamon- gan menunjukkan tentang unggul dan terampil dan juga dalam misi menumbuhkan teknologi yang seimbang, pembelajaran aktif, kreatif, efektif, inovatif, menyenangkan, berbabis karakter, ICT. Untuk lebih jelas bisa dilihat pada visi-misi MAN 1 Lamongan.

Visi Madrasah yaitu "Terwujudnya Generasi Islam yang Unggul dalam Prestasi, Terampil dan berbudaya lingkungan hidup pada tahun 2020". Sedangkan Misi Madrasah adalah 1). Menumbuh kembangkan sikap dan perilaku Islami dalam kehidupan sehari-hari, 2). Menumbuhkan semangat belajar ilmu agama, ilmu pengetahuan dan teknologi yang seimbang, 3). Menyelenggarakan pendidikan diniyah melalui asrama, 4). Penyelenggaraan kegiatan pembelajaran aktif, kreatif, efektif, inovatif, menyenangkan, berbabis karakter, ICT, dan lingkungan hidup, 5). Menyiapkan SDM yang kompeten dan kompetitif, 6). Menyelenggarakan program keterampilan yang sesuai kebutuhan peserta didik dan masyarakat. Adapaun Tujuan MAN 1 Lamongan adalah Meningkatnya Penguasaan dan penerapan ajaran Islam pada keseharian perilaku baik ketika di madrasah maupun di rumah, Meningkatnya Akuntabilitas Kinerja MAN 1 Lamongan, Meningkatnya pelayanan terhadap penyelenggara negara (pegawai/guru), Meningkatnya kualitas dan kuantitas Sarana dan Prasarana Madrasah, Meningkatnya kualitas proses Pembelajaran, Meningkatnya intensitas Kegiatan Ekstra Kurikuler, dan Meningkatnya Penguasaan keterampilan (life skill).

Problem sebagaimana yang ditemukan oleh Ahmed et al. (2018) dan keunggulan dalam memanfaatkan e-learning sebagaimana hasil penelitian Bashir (2019) dapat menjadi pemicu bagi MAN 1 Lamongan. Bagi sistem pendidikan yang memiliki visi-misi yang jelas, maka sistem pendidkan tersebut akan terarah untuk mencapai tujaun dari pendidikannya melalui rumusan visi-misi, dan tujuannya. Halangan apapun yang menjadi faktor akan diurai dalam bentuk kegiatan yang realistis untuk menyelsaikan hambatan-hambatan kelembagaan. Bagi dunia Pendidikan visi, misi, dan tujuan meruakan arah pengembangan kemajuan Pendidikan. Hal tersebut diperkuat dengan hasil wawancara dengan Kepala MAN 1 Lamongan: “ Perumusan visi-misi, dan tujuan dari MAN 1 Lamongan menjadi nyawa pengegrak semua aktivitas bagi madrasah ini dalam mecapai tujuan. Dengan harapan bahwa semua stakeholders madrasah memiliki tujuan yang sama dalam mecapai tujuan yang dicitacitakan melalui ruusan visi-misi”.

Pembelajaran berbasis digital learning menjadi salah satu keunggulan di MAN 1 Lamongan ini memiliki layanan pembelajaran inovatif dengan menggunakan media pembelajaran seperti para pendidik yang dalam proses pembelajarnnya menggunakan 1). slide, Slide plus suara (tape) dan multiimage, 2). Visual dinamis yang di proyeksikan, meliputi filem, telivisi, dan video, 3). Cetak yang meliputi buku teks, modul, teks terprogram, workbook, majalah ilmiah berkala, dan lembaran lepas, 4). Permainan yang meliputi teka teki, simulasi, dan permainan papan, 5). Realia yang meliputi model, spacimen (contoh), dan manipulative (peta, boneka). MAN 1 Lamongan juga mengembangkan media pembelajaran melalui dig- 
ital yaitu Media pembelajaran melalui internet. MAN 1 Lamongan mengembangkan digital madrasah untuk memudahkan pendidik, tenaga kependidikan dan peserta didik serta untuk menghemat kertas. Melalui digital yang ada di MAN 1 Lamongan para pendidik sudah bisa uplod RPP, Materi Pembelajaran dan lainnya.

\section{Inovasi Digital Learning dalam Pengembangan Pendidikan Karakter pada Pembelajaran}

Penelitian Sohrabi et al. (2019) menemukan bahwa pemanfaatan e-laearning dapat meningkatkan kerja kolaboratif. Hal tersebut bermakna bahwa dengan e-laernng menjadi sarana dalam meningkatkan karakter tim. Kerja kolaboratif memiliki banyak muatan karakter. Misalnya kerjasama, saling menghargai, percaya diri, dan gemar membaca. Demikian juga hasil penelitian Sudirman (2019) melihat bahwa pendidikan karakter sukses ditanamkan kepada siswa oleh guru yanag memiliki sertifikat pendidik. Guru yang memiliki sertifikat pendidik tersebut salah satunya adalah guru yang memiliki kepekaan terhadap tuntutan abad-21 termasuk pemanfaatan IT dalam pembelajaran. Karakter yang ditemukan adalah sikap pengembangan berorientasi budaya dan toleransi. Kedua penelitian tersebut diatas sejalan dengan apa yang ditemukan dalam penelitian ini. Melalui pemanfaatan Teknologi oleh MAN 1 Lamongan, akhirnya muncul sebuah budaya tentang bagaimana memanfaatkan online secara baik atau internet positif. Guru dan murid memanfaatkan e-learning dalam proses pembalajaran dengan menggunakan insternet positif dengan menggunakan media pembelajaran yang bervariasi berupa slide, visual dinamis yang di proyeksikan, cetak, game, dan media realita. Keberagaman sarana tersebut akan membantu siswa dalam memperoleh pembiasaan kreatif dan kriris. Fasilitas-fasilitas ini digunakan oleh MAN 1 lamongan sebagai penggerak pendidikan karakter berbasis Teknologi Informasi. Media Pembelajaran dapat juga menggrakkan siswassiwi dalam berfikri kritis. Hal tersebut sejalan dengan temuan penelitian Wati (2020). Dia menemukan bahwa penggunaan media yang sesuai dengan karakteristik siswa dapat meningkatkan metakognitif siswa dalam pembelajaran Seni Rupa di Program Studi PGSD Universitas Muhammdiyah Sidoarjo.

Demikian juga hal tersebut diperkuat dengan respondent 1: " saya sangat suka dengan pola pembelajaran yang dilakukan oleh bapak-ibu guru saya. Saya punya tantangan dalam mengerjakan tugas-tugas yang diberikan oleh Guru“. Demikian juga respondent 12: “ saya menjadi giat belajar, karena saya suka dengan permainan atau game yang harus saya kerjakan "Upaya lain yang dilakukan oleh MAN 1 Lamongan dalam memanfaatkan penggunaan internet positif adalah memblokir internet yang memiliki akun-akun negatif. Internet yang digunakan oleh peserta didik MAN 1 Lamongan adalah untuk mengembangkan referensi-referensi mata pelajaran dan untuk mengakses materi-materi yang sudah di-uplod oleh para pendidik.

[Table 1 about here.]

\section{Inovasi digital Learning dalam Progam Kegiatan MAN 1 Lamongan}

Program kegiatan yang dilakukan oleh MAN 1 Lamongan melalui inovasi digital learning diantaranya 1) Kegiatan ekstrakulikuler yang ada di MAN 1 Lamongan yaitu: Qiro'atul Qur'an, Banjari/gambus, Muhadhoroh, Pramuka, UKS, PKS, KIR, Tataboga, Paskibraka, MANPALA, PMR, Futsal, Volly, Bola Basket, Bulu tangkis, Musik atau Band, Drum Band (Marching Band), Teater; 2) Program sekolah adiwiyata, 3) Program penjaminan mutu yang terdaftar dalam ISO; 4) Progam prodistik setara D1 yang bekerja sama dengan ITS meskipun pelajaran TIK sudah dihapus dari kurikulum; 5) Ma'had putra dan putri yang diwajibkan untuk jurusan keagamaan, kelas unggulan dan akselerasi pada waktu itu, tetapi setelah kelas unggulan dan akselerasi dihapus maka yang diwajibkan adalah jurusan keagamaan dan jika kuota masih ada dari kelas regular pun bisa untuk masuk di ma'had. Tambahan program yang lain adalah hari Senin diadakan kegiatan Upacara di lapangan utama MAN 1 Lamongan. Semebtara pada hari jumat diadakan volly ceria untuk guru dan karyawan. Pada hari Jumat pada minggu pertama dan minggu ketiga dilakukan Jumat bersih. Demikian juga pada setiap hari dilaksanakan sholat Dhuha diwajibkan untuk jurusan keagamaan berjama’ah di masjid Darussalam MAN 1 Lamongan dan jurusan selainnya ada yang ikut berjamaah dan ada pula yang sholat dhuha sendirian.

MAN 1 Lamongan juga menetapkan Slogan yang merupakan tata nilai (core value) dan kultur budaya yang harus dipraktekkan dalam kehidupan keseharian warga madrasah disingkat SSIIPSS yaitu 1). Salam, artinya ketika saling bertemu baik bertatap muka maupun dalam komunikasi awal hendaknya diawali dengan ucapan Assalamu'alaikum warrahmatullahi wabarakatuh. 2). Senyum bermakna bahwa saat bertatap muka hendaknya semua warga madrasah saling melemparkan senyum. Salah satu contoh Penerapan slogan pertama dan kedua ini adalah saat pertama kali siswa dan guru memasuki pintu gerbang madrasah disambut oleh piket siswa dan guru yang siap menyambut kedatangan siswa dan guru dengan ucapan salam dan senyuman. 3). Iqro' artinya baca artinya semua warga madrasah hendaknya membiasakan budaya membaca Alquran dan bacaan bacaan ilmu pengetahuan. Salah satu contoh terapan dari slogan ini yang telah dilakukan adalah setiap pagi sebelum pembelajaran dimulai kegiatan di kelas diawali dengan membaca Alqur'an bersama sama dan dilanjutkan dengan kegiatan Language habit. 4). Infaq diartikan sebagai memberikan sebagian harta untuk suatu kepentingan yang diperintahkan oleh Allah, hal ini diterapkan di madrasah dalam bentuk pemberian Infaq masjid. 5). Puasa, merupakan budaya 
yang diharapkan di madrasah yaitu melaksanakan puasa wajib dan sunnah. Hal ini menjadi budaya di MAN 1 Lamongan pada saat hari Senin dan Kamis tidak diperkenankan untuk menyediakan konsumsi pada kegiatan rapat dan pertemuan. 6). Shalat jama'ah, artinya pada jam-jam shalat hendaknya warga madrasah melaksanakannya secara bersama-sama baik di masjid maupun musholla yang telah disediakan. 7). Silaturrahim artinya saling berkunjung, Hal ini sudah merupakan budaya yang telah lama dijalankan di madrasah, Pada saat siswa maupun warga madrasah sakit atau mempunyai hajatan atau lainnya maka diantara warga madrasah selalu dikunjungi.

Core value tersebut menjadi kekuatan pendidikan karakter di Madrasah ini. Pelayanan pada program-program yang dimiliki oleh MAN 1 Lamongan juga tertintegrasi dalam suatu sistem IT. Dengan demikian kekuatan atau novelty dari penelitian-penelitian ini dengan penelitian yang lain seerti yang dilakukan oleh Ahmed et al. (2018); Bashir (2019); Sohrabi et al. (2019); Sudirman (2019); Wati (2020) adalah keterpaduan pelayanan IT dengan pembentukan karakter pendidikan yang dirumuskan melalui core valueyang berupa SSIIPSS. Model pengembangan karakter yang dimiliki oleh Sekolah/madrasah tertentu akan menjadi penciri dan lebih bermakna untuk mencapai tujuan pendidikan karakter tertentu, karena berbasis pada pada lokal wisdom yang dimiliki oleh lembaga pendidikan tersebut Nida (2019); Wang et al.

\section{REFERENCES}

Ahmed, M. U., Hussain, S., and Farid, S. (2018). Factors Influencing the Adoption of e-Learning in an Open and Distance Learning Institution of Pakistan. Electronic Journal of E-Learning 16, 148-158.

Arsyad, A. (2005). Media Pembelajaran (Jakarta: PT. Raja Grafindo Persada), 1258 .

Bashir, K. (2019). Modeling E-Learning Interactivity, Learner Satisfaction and Continuance Learning Intention in Ugandan Higher Learning Institutions. International Journal of Education and Development Using Information and Communication Technology 15, 1-21.

Effendi, E. and Zhuang, H. (2005). E-learning Konsep dan Aplikasi (Yogyakarta: Andi), 1-223.

Jenkins, M. and Hanson, J. (2003). E-Learning Series : A Guide for Senior Managers (New York: LSTN Generic Center).

Koran, J. K. C. (2000). Aplikasi “E-Learning” Dalam Pengajaran Dan Pembelajaran Di Sekolah-Sekolah Malaysia: Cadangan Perlaksanaan Pada Senario Masa Kini, Pasukan Projek Rintis Sekolah Bestari Bahagian Teknologi Pendidikan. Pasukan Projek Rintis Sekolah Bestari Bahagian Teknologi Pendidika 1, 1-13.

Kusuma, D. (2004). Pendidikan Karakter (Jakarta: Grasindo).

Mulyasa, E. (2011). Manajemen Pendidikan Karakter (Jakarta: PT Bumi Aksara).

Nida, T. (2019). A lesson plan model for character education in primary education. Educational Research and Reviews 14, 130-139. doi: 10.5897/err2018.3616.

Purwati, E., Mukaffa, Z., Syafi'i, Thohir, M., Rusydiyah, E. F., and Huda, M. N. (2012). Pendidikan Karakter: menjadi berkarakter muslim-muslimah Indonesia (Surabaya: Kopertais IV Press).

Rusman, Kurniawan, D., and Riyana, C. (2013). Pembelajaran Berbasis Teknologi Informasi dan Komunikasi (Jakarta: Rajawali Pers), 1-442.

Samani, M. and Hariyanto (2012). Konsep Dan Model Pendidikan Karakter (Bandung: Remaja Rosdakarya).

Sanaky, H. A. (2015). Media Pembelajaran Interaktif-Inovatif (Yogyakarta: Kaukaba Dipantara).
(2018) .

\section{KESIMPULAN}

Inovasi Media Pembelajaran Berbasis Digital dalam Pengembangan Pendidikan Karakter yang ada di MAN 1 Lamongan tecermin dalam tiga bagian. 1) dorongan Visi-misi MAN 1 Lamongan, 2) proses pembalajaran dengan menggunakan internet positif dengan menggunakan media pembelajaran yang bervariasi berupa slide, visual dinamis yang di proyeksikan, cetak, game, dan media realita, dan 3) progam kegiatan yeng meliputi program sekolah adiwiyata, program ISO, progam prodistik setara D1 yang bekerja sama dengan ITS, dan Ma'had putra dan putri yang terhubung dengan layanan Teknologi Informasi.

\section{UCAPAN TERIMA KASIH}

Peneliti menyampaikan ucapan terima kasih yang sebesarbesarnya kepada MAN I Lamongan yang telah memberikan kesempatan kepada peneliti untuk pengambilan data serta keleluasaan dalam melakukan penelitian serta pengolahan data secara maksimal.
Sanjaya, W. (2008). Kurikulum dan Pembelajaran (Teoritik dan Praktik Kurikulum KTSP) (Jakarta: Prenada Media Group).

Sohrabi, B., Vanani, I. R., and Iraj, H. (2019). The Evolution of E-Learning Practices at the University of Tehran: A Case Study. Knowledge Management \& E-Learning: An International Journal 11, 20-37. doi: https://doi.org/10.34105/j.kmel.2019. 11.002 .

Sudirman (2019). The 21st-Century Teacher: Teacher's Competence Within the Character Education Framework Towards A Cultural-Oriented Development and Promoting Tolerance. International Education Studies 12, 21-21. doi: 10.5539/ies.v12n8p21.

Suryani, T. (2008). Perilaku Konsumen Implikasi Pada Strategi Pemasaran (Yogyakarta: Pustaka Pelajar Grup).

Wang, S., Iwata, J., and Jarrell, D. (2018). Exploring Japanese Students' E-Learning Habits. JALT CALL Journal 14, 211-223.

Wati, T. L. (2020). Analisis Metakognitif Melalui Media Pada Matakuliah Seni Rupa Mahasiswa Pendidikan Guru Sekolah Dasar Metacognitive. PEDAGOGIA. Jurnal Pendidikan 9, 35-42. doi: https://doi.org/10.21070/pedagogia.v9i1.214.

Widyartono, D. (213). Pembelajaran Inovatif Bahasa Indonesia Melalui Alih Media Buku Pelajaran Kurikulum 2013. Jurnal LP3 Universitas Brawijaya 2, 40-46. doi: https://doi.org/.

Conflict of Interest Statement: The authors declare that the research was conducted in the absence of any commercial or financial relationships that could be construed as a potential conflict of interest.

Copyright (c) 2020 Rusydiyah, Mumtahanah and Hamzah. This is an open-access article distributed under the terms of the Creative Commons Attribution License (CC BY). The use, distribution or reproduction in other forums is permitted, provided the original author(s) and the copyright owner(s) are credited and that the original publication in this journal is cited, in accordance with accepted academic practice. No use, distribution or reproduction is permitted which does not comply with these terms. 


\section{LIST OF TABLES}

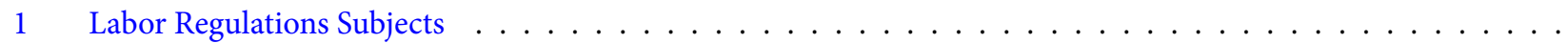


TABLE 1 | Labor Regulations Subjects

Labor agreement

(Article 1/14 Act 13/2003

Labor relationship

(Article 1/15 Act 13/2003)
Industrial relationship

(Article 1/15 Act 13/2003)
Industrial relation of dispute (Article 1/15 Act 13/2003 jo. Article 56 Act No. 2/2004)
1. Worker
2. Entrepreneur
3. Employer
4. Entrepreneur 5. Worker

1. ntrepreneur-worker

2. Entrepreneurs- workers

3. Entrepreneur- trade union

4. Entrepreneurs-trade

uniontrade union-trade union 